\title{
インフラ維持管理技術の変化によるマクロ経済的影響に関する基礎的モデル分析 An Analysis of Macroeconomic Effects by the Change of Infrastructure Management Technology*
}

\author{
石倉智樹 ${ }^{* *}$ \\ By Tomoki ISHIKURA**
}

\section{1. はじめに}

日本経済には多くのインフラストックが蓄積 ${ }^{1) さ れ て ~}$ いるが，今後の維持管理費，老朽化したストックの更新 費用などが増大寸ることが予想されている ${ }^{2)}$. 行政にお いても，戦略的な維持管理・更新が重視されつつある ${ }^{3)}$. また，維持管理・更新に関する工学的技術，例えば, 検査技術，劣化予測技術，長寿命化技術や，アセットマ ネジメントに関する技術は進歩している ${ }^{4)}$. しかし，都 市におけるインフラマネジメント，国におけるインフラ マネジメント，のような空間的にマクロな視点からのイ ンフラマネジメント，特に維持管理・更新に関する研究 は, 個別インフラのアセットマネジメントに比べると， 未だ蓄積が少ない.

インフラーの投資と経済成長の関係については，古く から研究されている分野の一つであり，理論的モデルも 実証研究も蓄積されている。 それらは，新規投資による インフラストック量蓄積に注目したものが多かった. し かし，近年になり，維持更新や投資の効率性についても， 注目されつつある。

本研究は, 長期的な視点からインフラの戦略的な維持 管理・更新政策への示唆を得るため, インフラの維持管 理技術の変化がマクロ経済的な成長に及ぼす影響を考察 するための基礎的な動学的経済モデルを構築する. さら に，仮想経済を対象としたシミュレーション分析により， インフラの維持管理技術の変化や，インフラストックの 生産性の変化が，最適成長のためのインフラ投資・維持 管理政策に及ぼす影響について，感度分析を行う。

\section{2. インフラと長期経済モデルに関する既存研究}

経済モデルにおいて，インフラストラクチヤは，公的 セクターすなわち政府部門による投資によって蓄積され た資本ストックとして定義されることが一般的である. このような観点からインフラストックと経済成長の関係

*キーワーズ : 計画基礎論, 維持管理計画, 経済成長

**正員, 博 (情報科学) , 東京大学大学院社会基盤学専攻

(東京都文京区本郷 7-3-1，TEL\&FAX: 03-5841-0566

E-mail: ishikura@csur.t.u-tokyo.ac.jp)
に着目し，動学モデルとして扱った研究は Arrow and Kurz ${ }^{5}$ が確立したと言えよう. Arrow and Kurz" 資本ストック蓄積による生産能力向上をモデル化し, 最 適な公的投資政策について理論的解析をおこなった。

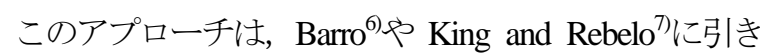
継がれて発展を見せた．Barro6は，政府の役割に着目し， 政府の規模と成長の関係や税制と成長率の関係について 論じている. King and Rebelo では, 人的資本形成を考 慮した内生成長モデルの枠組みにおいて，税制が成長率 に及ぼす影響を分析した.しかし，これらはいずれも， モデル分析の主眼が財政・税制政策にあり，インフラ自 体の特性とその経済成長への関連については, 重点を置 かれていない，また，ストックとしてのインフラは扱わ れていない.

これらに対して，インフラストックの特性に着目した Glomm and Ravikumar ${ }^{8}$ は，道路，空港，港湾なじを例に， 物的インフラが混雑による影響を受けるという特性を明 示し，完全非競合性を仮定していた，公的ストック=公 共財型のモデルと差別化されている. Glomm and Ravikumar) では，インフラ投資への最適財政配分が，イ ンフラストックの混雑状況と独立に決定されるという興 味深い結論を導出している.

Aschauer による実証研究 9)以来，インフラへの投資が 経済成長へ寄与しうるかという論点が活発化した. この 点について, Devarajan et al. $\left.{ }^{10}\right)$ は, 公的支出の配分に着目 し，発展途上国においてはインフラストックへの投資よ りも, 維持管理・運営など非投資支出の方が, 経済成長 への寄与度が高いという実証結果を示した. Devarajan et al. ${ }^{10)}$ による実証結果を受けて, Rioja ${ }^{11)}$ は，インフラスト ックの維持管理を明示した成長モデルを構築し, 維持管 理による経済成長への影響を分析した。このモデルは, 政府の維持管理支出に依存してインフラストックの減耗 率が内生的に決定される枠組みであり，すなわちインフ ラストックの劣化が制御されうる構造となっている.ま た，Rioja ${ }^{11}$ は，モデルをラテンアメリカ諸国に適用し， 現状の維持管理支出は最適水準よりも小さく，インフラ 投資を維持管理へ配分することで，より高い経済成長率 を実現できるだろうと述べている。

Rioja ${ }^{11)}$ のモデルでは，インフラへの投資が全て海外か らの援助によりファイナンスされるという特殊な仮定が 設けられていた. したがって, 当該国の政府による, 新 
規投資と維持管理への配分は考慮されていない. Kalaitzidakis and Kalyvitis ${ }^{12}$ は, 政府が新規投資と既存又 トック維持管理への支出配分を行う内生的成長モデルを 構築し, 最適な支出配分, すなわち最適財政政策の特性 を議論している. Kalaitzidakis and Kalyvitis ${ }^{12)}$ のデルで は，内部調整費用として，民間資本のストック調整費用 も考慮されており，民間資本と公的資本がともに，バラ ンスシート上の金銭的資産としてのストックではなく固 定資本ストックを意識して扱われている.

桑島, 織田澤 ${ }^{13)}$, Dioikitopoulos and Kalyvitis ${ }^{14}$ は, Kalaitzidakis and Kalyvitis ${ }^{12)}$ の枠組みに加えて, Glomm and Ravikumar ${ }^{8)}$ が扱ったインフラの混䧱影響を考慮して いる. これらは，民間資本ストックとインフラストック の差別化, 維持管理の明示, 減耗 (劣化) の制御, 混杂隹 の影響など，土木分野において工学的研究が取り扱って きた技術的要素を, 動学的一般均衡モデルの中で明示的 に位置づけて考慮している. したがって，インフラ管理 技術とマクロ経済との関連を考察するための経済モデル としての土台が確立しつつあると言える.しかし，桑島， 織田澤 ${ }^{13)}$, Dioikitopoulos and Kalyvitis ${ }^{14)}$ の視点は, 課税 税率にあり，技術革新の効果や技術選択のような，工学 技術とマクロ経済の関係については論じられていない.

上田, 横松 ${ }^{15)}$ や筆者による研究 ${ }^{16)}$, 上田ら ${ }^{17}$ は, 混 杂倠効果やストック調整費用を簡略化するなど，上記のモ デルに比べて単純な枠組みであるが，よりインフラ管理 技術の長期的効果に焦点をおいた分析を行っている. 寸 なわち，投資の効率性や劣化の制御など，工学的技術を 経済成長モデルにおいて明示的に位置付けることが試み られている. 今後, マクロな視点からのインフラマネジ メント政策を研究するにあたり, こうした動学的マクロ 経済モデルとインフラ管理技術を融合させる方法が，標 準的アプローチの一つになりうる.

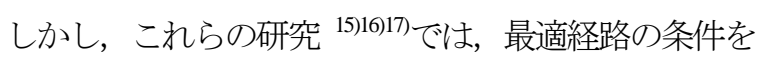
基に，比較動学的に解の傾向を論じるに留まっている.

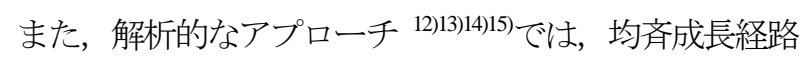
における解の特性分析に主眼がおかれているが，現実の 経済が均斉成長経路上にあることは保証されておらず, また政策的示唆という観点からは, 任意の経済状態に対 して望ましい政策を論じることが求められる. 本研究は, 将来的に実データを用いた応用一発展寸ることを見据え， 動学的推移の数值的な分析が容易となるよう, 既存の理 論研究における知見との関係性を維持しつつ, 上記の既 存研究では扱われていなかった, シミュレーションに適 した離散型の動的計画法に基づくモデル展開を行う.さ らに, 技術変化ショックによる経済成長経路や最適政策 への定量的影響について感度分析を行う。

\section{3. インフラ管理技術を考慮した基本的な動学的一般均 衡モデルの構造}

(1)モデル

a) 概要

前章で述べたように，インフラ管理技術を考慮した動 学的一般均衡モデルは, 工学的技術のマクロ経済的役割 を分析するための有用な方法の一つと考えられる. そこ で本節では, 桑島・織田澤 ${ }^{13)}$ や Dioikitopoulos and Kalyvitis ${ }^{14)}$ に倣い，政府投資と政府によるインフラ維持 管理を考慮した，閉鎖経済動学的一般均衡モデルを構築 し，これを用いて，インフラ管理技術のマクロ経済への 影響と最適インフラ管理支出についての基本的な特長を 検討する.

b) 代表的家計の行動

代表的家計は，各期の所得制約の下で，無限視野にお ける効用を最大化するように消費流列を決定する.

$$
\max _{\left\{C_{t}\right\}_{0}^{\infty}} \int_{0}^{\infty} u\left(C_{t}\right) e^{-\rho t} d t
$$

ここで，C: 消費， $\rho$ は割引率を表す，ただし，スクリプ 卜 $\mathrm{t}$ は時点を表すものであり, 以下も同様である. 代表 的家計は, 以下の異時点間弾力性一定型の瞬時効用関数 を持つと仮定する.

$$
u\left(C_{t}\right)=\frac{C_{t}^{1-\sigma}-1}{1-\sigma}
$$

ここで， のは異時点間代替弾力性の逆数である. 代表的 家計は, 労㗢力と民間資本ストックを所有しており, 労 働所得と資本所得を収入として得て, 消費および投資と して支出する. したがって, 所得制約は次のように表わ される.

$$
C_{t}+I_{t}=w_{t} L_{t}+r_{t} K_{t}
$$

ここで，K: 民間資本， $L$ : 労働， $I$ : 投資，w: 賃金率， $r$ : 民間資本レントをそれぞれ表す。

c) 代表的企業の行動

次に, 代表的企業の行動をモデル化する. 生産関数を, 民間資本投入と労㗢投入に関して一次同次である CobbDouglas 関数と仮定する.

$$
Y_{t}=A \cdot\left(K_{G t}\right)^{\theta}\left(K_{t}\right)^{\alpha}\left(L_{t}\right)^{1-\alpha}
$$

ここで, $Y$ : 生産, $K_{G}$ : インフラストック $A$ : 技術指標 であり， $\theta$ と $\alpha$ は, 代替パラメータである. 代表的企業 は, 価格受容者として, 各期の利潤を最大化するように, 民間資本ストックと労働の投入量を決定する. 企業にと って, 期首インフラストックの水準は与件となる.

$$
\max _{K_{t}, L_{t}} \Pi=(1-\tau) Y_{t}-w_{t} L_{t}-r_{t} K_{t}
$$

ここで，ては税率を表し，生産に対して定率課税されて 
いると仮定する，一階の条件より，

$$
\frac{\partial \Pi}{\partial K_{t}}=0, \frac{\partial \Pi}{\partial L_{t}}=0
$$

であるため，以下のように要素価格が得られる.

$$
\begin{aligned}
& r_{t}=(1-\tau) \alpha \frac{Y_{t}}{K_{t}} \\
& w_{t}=(1-\tau)(1-\alpha) \frac{Y_{t}}{L_{t}}
\end{aligned}
$$

なお，(3)，(7)，(8)より，以下の関係が成立する.

$$
C_{t}+I_{t}=(1-\tau) Y_{t}
$$

d) 政府の行動

政府は，生産物税を原資として，インフラ投資と維持 管理へ支出を配分寸る.

$$
I_{G t}+M_{t}=\tau Y_{t}
$$

ここで， $I_{G}$ : インフラ投資， $M$ : 維持管理である.

e) 資本蓄積過程

民間資本ストックは，家計投資により増加し，各期一 定の割合で咸耗寸ると考える.インフラストックは，政 府のインフラ投資により蓄積されるとともに，各期に劣 化・滅失する. しかし, インフラの劣化・滅失は維持管 理の度合いによって制御することができる.

$$
\begin{aligned}
& \dot{K}_{t}=I_{t}-\delta K_{t} \\
& \dot{K}_{G t}=I_{G t}-\delta_{G}\left(M_{t}, K_{G t}\right)
\end{aligned}
$$

ここで， $\delta$ は民間資本ストックの減耗率を表し， $\delta_{\mathrm{G}}\left(M_{t}\right.$ $\left.K_{G t}\right)$ は，インフラストックの劣化・滅失関数を表す.

\section{(2)最適政策と成長経路}

以上で構築されたモデルについて，代表的家計の効用 を最大化するように政府の政策が決定される，すなわち 社会的最適となる解を考える. なお，政府の行動を外生 とした場合の解は，競争均衡における分権解となる ${ }^{14)}$. (1)の動的最適化問題に, 政府の政策であるインフラ投 資と維持管理費を制御変数に加えることで, 社会的最適 となる解 (集権解) を導出する問題となる. (9)と(10)の 関係より,

$$
I_{t}=Y_{t}-C_{t}-I_{G t}-M_{t}
$$

であり, 各期の生産は(4)のとおり, 期首ストックで先 決されているため，民間資本ストックへの投資は，消費， インフラ投資，維持管理費が決定されると自動的に決定 される. そして, これらの配分比率より, 結果的に最適 税率枋実現されることとなる.

したがって，社会的最適のための動的最適化問題は， $\max _{\left\{C_{t}, M_{t}, I_{G}\right\}_{0}^{\infty}} \int_{0}^{\infty} \frac{C_{t}^{1-\sigma}-1}{1-\sigma} e^{-\rho t} d t$

s.t.

式 (4), (11), (12), (13)

と書き改めることができる.この問題の解となる最適経 路の条件は, 下記に定義される当期価值八ミルトニアン 最大化問題を解くことにより得られる ${ }^{18)}$.

$$
\begin{aligned}
\max _{C_{t}, M_{t}, I_{G t}} H= & \frac{C_{t}^{1-\sigma}-1}{1-\sigma} \\
& +\lambda\left[Y_{t}-C_{t}-I_{G t}-M_{G t}-\delta K_{t}\right] \\
& +\eta\left[I_{G t}-\delta_{G}\left(M_{t}, K_{G t}\right)\right]
\end{aligned}
$$

入および $\eta$ は随伴変数である. この全ての制御変数に内 点解を仮定すれば, 最大值原理より, 以下の条件が得ら れる.

$$
\begin{gathered}
C_{t}^{-\sigma}-\lambda=0 \\
\lambda+\mu \frac{\partial \delta_{G}\left(M_{t}, K_{G t}\right)}{\partial M_{t}}=0 \\
\lambda-\mu=0 \\
\dot{\lambda}-\rho \lambda+\lambda\left[\alpha \frac{Y_{t}}{K_{t}}-\delta\right]=0 \\
\dot{\mu}-\rho \mu+\mu\left(-\frac{\partial \delta_{G}\left(M_{t}, K_{G t}\right)}{\partial K_{G t}}\right)=0
\end{gathered}
$$

$$
\lim _{t \rightarrow \infty} \lambda_{t} K_{t} e^{-\rho t}=0, \lim _{t \rightarrow \infty} \eta_{t} K_{G t} e^{-\rho t}=0
$$

(16)から(18)より，

$$
\begin{aligned}
& \frac{\dot{C}_{t}}{C_{t}}=-\frac{1}{\sigma} \frac{\dot{\lambda}_{t}}{\lambda_{t}}=-\frac{1}{\sigma} \frac{\dot{\mu}_{t}}{\mu_{t}}=g^{*} \\
& \frac{\partial \delta_{G}\left(M_{t}, K_{G t}\right)}{\partial M_{t}}=-1
\end{aligned}
$$

の関係が直ちに導出される. ただし， $g^{*}$ は消費の均衡成 長率を意味する. (18)より, 最適成長経路においては, 民間資本ストック蓄積のシャドウプライスとインフラ蓄 積のそれが等しく，これらの変化率が消費の成長率を決 定付ける要因になる. また, (23)よりインフラ劣化の維 持管理費に関する導関数が-1 であることが示されてい るが，これはインフラ蓄積のインフラ投資に関する導関 数が 1 であり, この值が維持管理によるインフラ蓄積の 効果と等しくなるためである. 
また，(18)，(19)の条件より，それぞれ

$$
\begin{aligned}
& \frac{\dot{\lambda}}{\lambda}=\rho+\delta-\alpha \frac{Y_{t}}{K_{t}} \\
& \frac{\dot{\mu}}{\mu}=\rho+\frac{\partial \delta_{G}\left(M_{t}^{*}, K_{G t}\right)}{\partial K_{G t}}
\end{aligned}
$$

という関係も得られる.ここで,

$M^{*}=M$ such that

$$
\frac{\partial \delta_{G}\left(M_{t}^{*}, K_{G t}\right)}{\partial K_{G t}}=\delta-\alpha \frac{Y_{t}}{K_{t}}
$$

であり，各期における最適維持管理政策の条件を表す。 したがって，消費の最適成長経路は，標準的なラムゼイ 型成長モデルと同様に,

$$
\frac{\dot{C}_{t}}{C_{t}}=\frac{1}{\sigma}\left(A \alpha\left(K_{G t}\right)^{\theta}\left(\frac{L_{t}}{K_{t}}\right)^{1-\alpha}-\rho-\delta\right)
$$

となり，ストックの蓄積経路は，民間資本ストック，イ ンフラストックそれぞれについて,

$$
\begin{aligned}
\frac{\dot{K}_{t}}{K_{t}}= & A(1-\tau)\left(K_{G t}\right)^{\theta}\left(\frac{L_{t}}{K_{t}}\right)^{1-\alpha}-\frac{C_{t}}{K_{t}}-\delta \\
\frac{\dot{K}_{G t}}{K_{G t}} & =A \tau\left(K_{G t}\right)^{\theta-1}\left(K_{t}\right)^{\alpha}\left(L_{t}\right)^{1-\alpha} \\
& -\frac{M_{t}^{*}}{K_{G t}}-\frac{\delta_{G}\left(M_{t}^{*}, K_{G t}\right)}{K_{G t}}
\end{aligned}
$$

となる.

\section{(3)インフラ管理技術に着目した含意}

(29)式からも明らかなように， $\delta_{G}$ の技術変化すなわち インフラの維持管理技術の変化は, インフラストックの (最適) 蓄積経路一直接的に影響を及ぼす。ささらに一 ンフラストックが生産的資本として考慮されているため, (27)(28)式が示すように，消費経路と民間資本ストック の蓄積経路に対しても，インフラストック水準が影響す ることが理解できる．維持管理をはじめとするインフラ の管理技術の発展がマク口経済の動きに及ぼす効果を評 価するためには，インフラストックの生産力とインフラ 管理技術のモデル化に注意を払う必要がある。

\section{4. 数值シミュレーションによる考察}

(1) モデルの離散時間化

本研究が扱うような動的最適化問題においては，モデ ルの関数型が複雑な場合や，状態変数や制御变数の次元 が多い場合には，陽表的な解析解を得ることが困難ある
いは不可能となることが知られている ${ }^{19)}$. そこで本章 では, 前章て提示したモデルに基づき, インフラの維持 管理技術の変化が, 成長経路や最適政策に及ぼす影響を 考察するため, 数值シミュレーションによる分析を行う. まず，モデルの数値的な取扱いを容易にするため, 時間 単位を離散的に表現する. また, 本研究のモデルでは扱 っていないが，確率的な要素をモデル几導入した場合一 の展開も考慮し, 動的最適化のアプローチとして動的計 画法を採用する. 前章に示した最適制御問題とは, 解へ のアプローチが異なるが，導出される解は同一である.

社会的最適のための目的関数は, 次の式により表わさ れる.

$$
\max _{\left\{C_{t}, M_{t}, I_{\left.C_{t}\right\}_{0}}\right.} \sum_{t=0}^{\infty} \beta^{t}\left(\frac{C_{t}^{1-\sigma}-1}{1-\sigma}\right)
$$

ここで，

各経済主体の行動については, 前章のモデルがそのま ま適用される，経済システム全体の市場清算条件は，

$$
Y_{t}=C_{t}+I_{t}+I_{G t}+M_{t}
$$

と表わされる. 民間資本ストックの蓄積過程は,

$$
K_{t+1}-K_{t}=I_{t}-\delta K_{t}
$$

と定義する. インフラストックの蓄積過程に関する維持 管理費と劣化・滅失の関倸に関しては, マクロな経済レ ベルでは，広く合意の得られた知見が存在していない． そこで，インフラストックに対する維持管理費の割合が 小さいほど，劣化・滅失が大きくなることを想定し，以 下のような蓄積過程を定義した。

$$
K_{G t+1}=I_{G t}+K_{G t}\left(\frac{M_{t}}{K_{G t}}\right)^{\gamma}
$$

インフラストックの劣化・滅失関数の形式で表すと,

$$
K_{G t+1}-K_{G t}=I_{G t}-K_{G t}\left[1-\left(\frac{M_{t}}{K_{G t}}\right)^{\gamma}\right]
$$

となる. 以上の前提条件の下での最適政策は, 以下のべ ルマン方程式の解となる政策関数として得ることができ る. なお，式(39)の非負制約により，前章のモデルとは 異なり，端点解も扱うことが可能である.

$$
V\left(K, K_{G}\right)=\max _{C, I, M, I_{G}}\left[\frac{C^{1-\sigma}-1}{1-\sigma}+\beta V\left(K^{\prime}, K_{G}^{\prime}\right)\right]
$$

s.t.

$$
\begin{gathered}
C+I+I_{G}+M=A\left(K_{G}\right)^{\theta}(K)^{\alpha}(L)^{1-\alpha} \\
K^{\prime}=I_{t}+(1-\delta) K
\end{gathered}
$$




$$
\begin{aligned}
& K_{G}{ }^{\prime}=I_{G}+K_{G}\left(\frac{M}{K_{G}}\right)^{\gamma} \\
& C \geq 0, I \geq 0, I_{G} \geq 0, M \geq 0
\end{aligned}
$$

(2) 数值シミュレーション

本節では, パラメータを特定化し, 数值シミュレーシ ヨンを行う。ここでは，基本ケースとして，表－1 に示 すパラメータおよび，政策関数の導出対象とする状態変 数の值を設定した. ただし, 生産関数の分配パラメータ と割引因子については，一般的なマクロ経済モデルで用 いられるものと近い值を設定したが，それ以外について は，仮想的な経済システムを想定したものである．シミ ユレーション分析では，維持管理技術およびインフラス トックの生産性に係るパラメータを操作し, モデル出力 に及ぶ影響の感度を観察する. 数值解を求める手法とし ては, Value Function Iteration 法 ${ }^{20)}$ を採用した。

\section{表-1＼cjkstart基本ケースのパラメータと状態変数の範囲}

\begin{tabular}{|c|c|}
\hline パラメータ名 & 値 \\
\hline$\alpha$ & 0.4 \\
\hline$\beta$ & 0.95 \\
\hline$\delta$ & 0.05 \\
\hline$\theta$ & 0.2 \\
\hline$\sigma$ & 1.1 \\
\hline$\gamma$ & 0.15 \\
\hline$A$ & 1 \\
\hline$K$ & $240 \sim 360$ \\
\hline$K_{q}$ & $80 \sim 120$ \\
\hline$L$ & 100 \\
\hline
\end{tabular}

まず，基本ケースにおけるモデルの挙動を簡単に述べ る. 図-1 から図-3 は，基本ケースにおいて，民間資本 ストックとインフラストック状態に対応した, 最適政策 としてのインフラ投資. 維持管理費，民間投資を表わし たものである. 図-1, 図-2 より, インフラストックの 蓄積が進むと，インフラ投資が減り維持管理費が増加し， 民間資本が蓄積されると, 逆に, 維持管理費を減らしイ ンフラ投資が増加するという傾向が確認される. 前者の 結果は，インフラストックが蓄積されると，その限界生 産性が低下寸るためと考えられる，民間資本の蓄積が維 持管理費を減らしインフラ投資を増加させることについ ては，式(4)の生産関数から明らかなように，民間資本 が蓄積すると，インフラストックの限界生産性が向上寸 るが，式(33)のとおり，インフラストックの維持管理費 と民間資本ストック水淮が独立であり相互に影響しない ことが影響していると考えられる.この結果の特性につ いては，インフラストックの維持管理費と民間資本スト
ックとの関係性が変化すると, 解の特性にも変化が生じ ると予想される.

民間投資についても，民間資本ストックの蓄積により 限界生産性が低下寸ると, 最適投資が減少する特性が表 現されている. また，民間資本ストックが小さな水準の 場合には，インフラストックが大きいほど最適民間投資 も大きくなっている.

維持管理技術を意味するパラメータ $\gamma$ を変化させたと きの, 最適経路におけるインフラストックと民間資本ス トックの状態変化を図-4から図-6に示寸.

図-4 から図-6 は, 当期のインフラストック $K_{G}$ と民 間資本ストック $K$ に対応した最適な次期インフラスト ック $K_{G}$ の值, 寸なわち $K_{G}$ の政策関数と, ベクトル場 として表わした $K_{G}$ と $K$ の変化の経路を示している. $\gamma$ の值が大きいほど，インフラストックの維持管理技術の 効率性が低く, 劣化・滅失を防ぐために多くの維持管理 支出が必要であることを意味する. 寸なわち，これらの シミュレーション結果より, インフラストックの維持管 理技術の効率性が低水準であるほど，次期インフラスト ック值の最適水準が低くなることが確認できる. 本シミ ユレーションは仮想的な経済システムと技術構造を仮定 したものであるが，この結果は，維持管理技術が効率的 でなければ, インフラストックを増加させることは効率 性の観点からは望ましくない，ということを示唆してい る. 特に, 民間資本ストックの水準が小さな領域（グラ フ中では左側）では, 当期のインフラストック規模が大 きいと，次期インフラストックが当期よりも小さくなる ことが最適政策となっている.

次に, インフラストックの限界生産性に関するパラメ 一タ $\theta$ を変化させたときの, $K_{G}$ の政策関数と, $K_{G}$ と $K$ の変化の経路一の影響を, 図-7 から図-9 に示寸. 基本 ケースである図-7 は図-4 と同一のものである. これら の結果より，特に民間資本ストックが小さく生産活動の 規模が低い状態の経済では，インフラストックの劣化・ 滅失を許容してストックを減少させるか，あるいはスト ックを増加させるか, その最適政策に対してインフラス トックの限界生産力が敏感に影響していることが確認で きる.

なお，いずれのケースにおいても，フロー変数である インフラ投資，維持管理費，民間投資の最適值を描いた 政策関数は，図-1 から図-3 と類似した形状が得られた. 


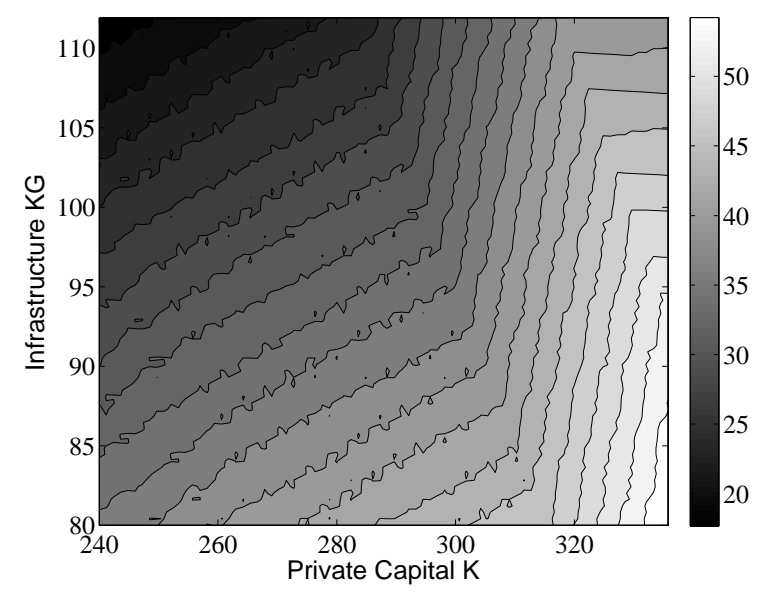

図-1 基本ケースにおける最適インフラ投資 $I_{G}$ の コンター

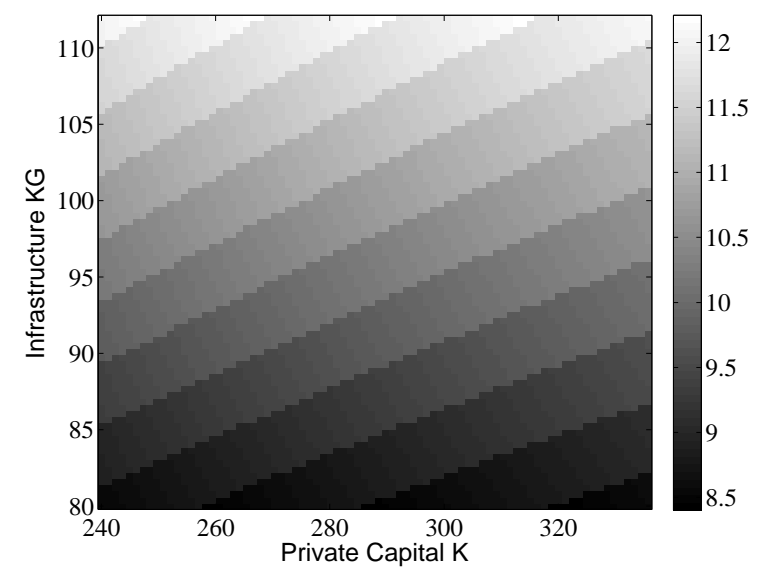

図-2 基本ケースにおける最適維持管理費 $M$ の コンター

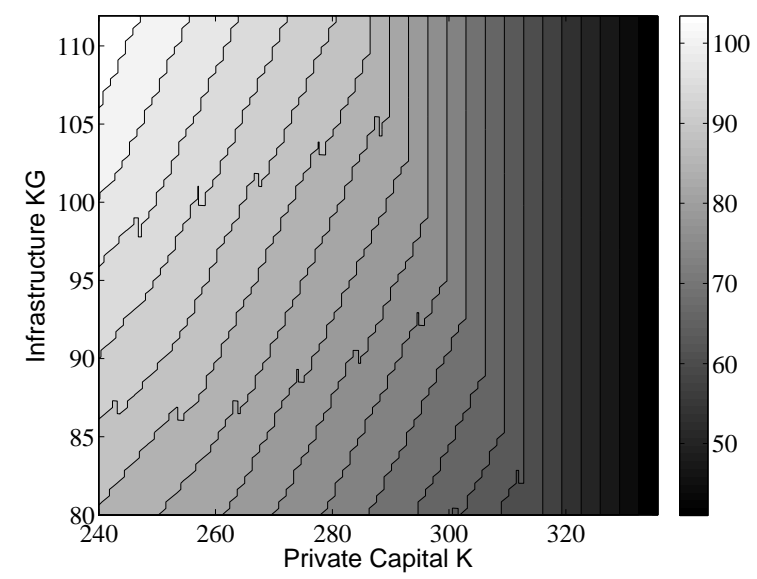

図-3 基本ケースにおける最適民間投資 $I$ の コンター

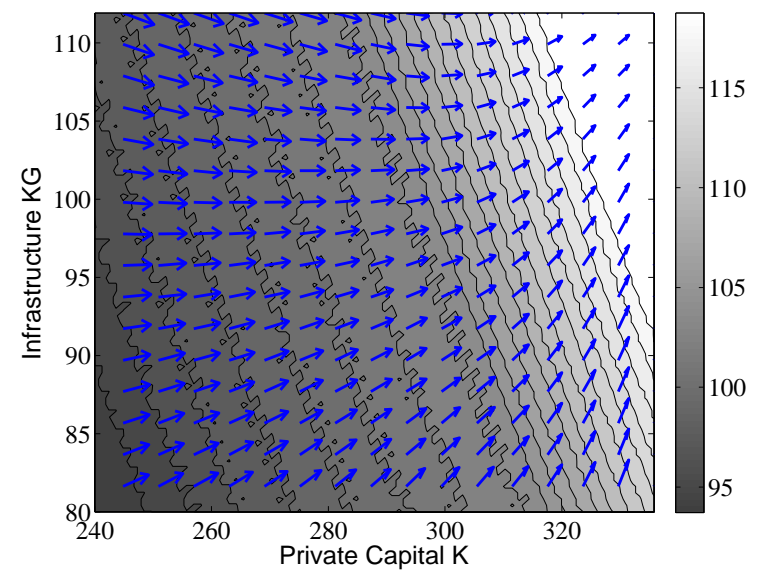

図-4 基本ケース $(\gamma=0.15)$ の場合における最適次期 $K_{G}$ のコンターおよび $K$ と $K_{G}$ の変化のベクトル場

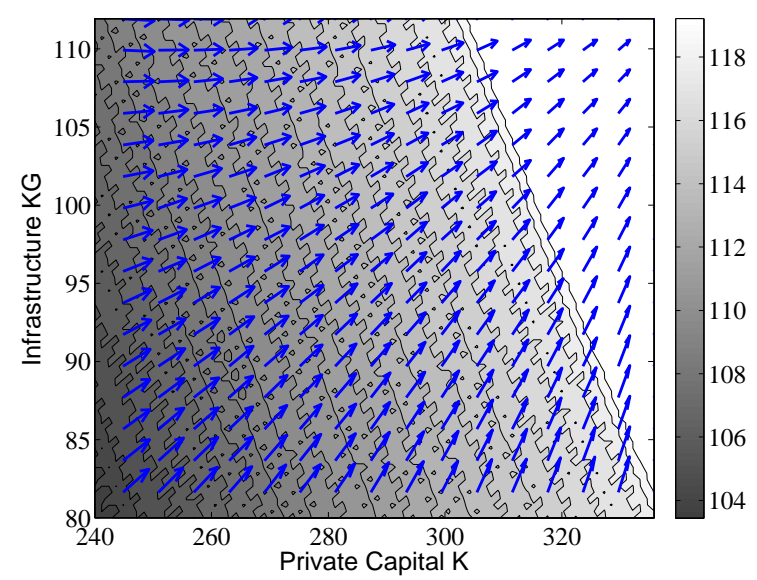

図-5 $\gamma=0.1$ の場合における最適次期 $K_{G}$ のコンターお よび $K$ と $K_{G}$ の変化のベクトル場

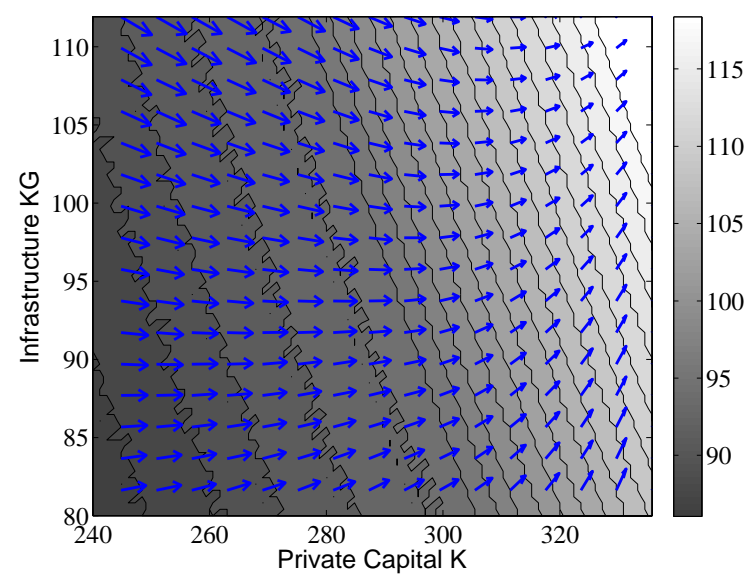

図-6 $\gamma=0.2$ の場合における最適次期 $K_{G}$ のコンターお よび $K$ と $K_{G}$ の変化のベクトル場 


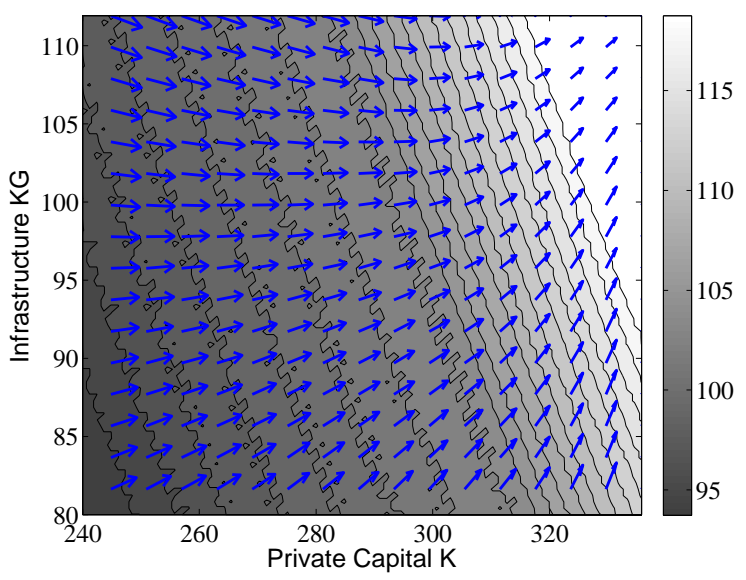

図-7 基本ケース $(\theta=0.2)$ の場合における最適次期 $K_{G}$ のコンターおよび $K$ と $K_{G}$ の変化のベクトル場

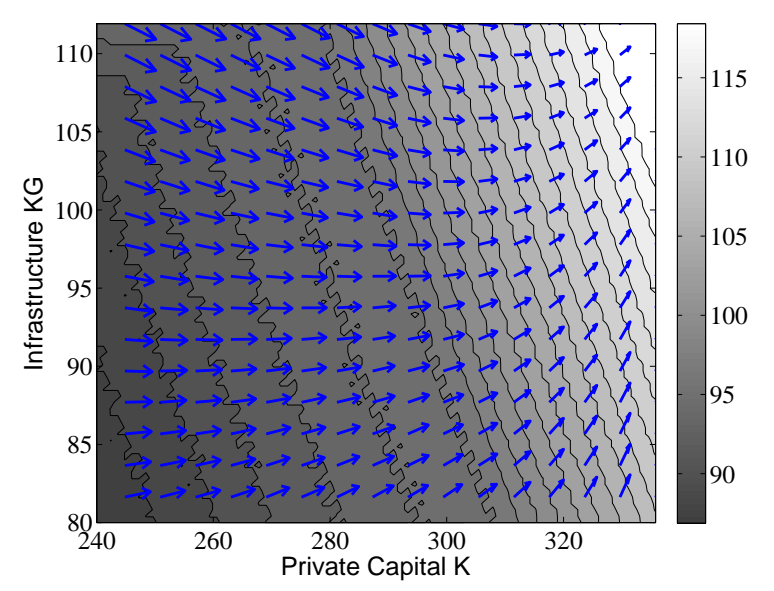

図-8 $\theta=0.19$ の場合における最適次期 $K_{G}$ のコンター および $K$ と $K_{G}$ の変化のベクトル場

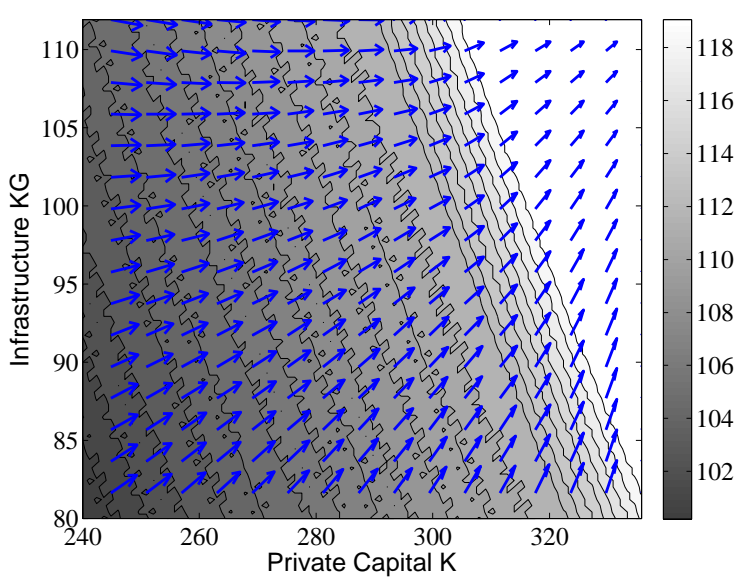

図-9 $\theta=0.21$ の場合における最適次期 $K_{G}$ のコンター および $K$ と $K_{G}$ の変化のベクトル場

(3) シミュレーション分析の課題と展望

本研究では, 仮想的な経済システムを想定して各種パ ラメータを設定し, 数值シミュレーションにより, 最適 政策の挙動を分析した. 現実経済を対象としてモデルを
適用するためには，インフラ管理技術に関するパラメー タを推定寸る必要がある. しかし，維持管理費とインフ ラストックの劣化・滅失の関係を，マクロ経済的視点か ら推定することは容易ではない. その場合にも, 生産関 数など, 相対的に関数形やパラメータの推定が容易な前 提条件を固定し，インフラ管理技術に関するパラメータ について感度分析を行うことで, 一定の幅を持った, 最 適な維持管理支出政策を導出することができる.

\section{5. おわりに}

本研究は, インフラの維持管理・更新政策への示唆を 得るため, 維持管理によるインフラストックの劣化・滅 失制御を明示したマクロ経済動学モデルを構築し, 数值 シミュレーションを通じて, 維持管理技術とインフラ投 資・維持管理政策との関係について感度分析を行った。 定性的結論は，解析的なモデル分析から得られる知見と 一致しているが, 本モデルは, 状態変数の任意の值に対 して, 定量的に最適政策 (インフラ投資額, 維持管理支 出）を導出することができることを示した.

解析的なアプローチでは，こうしたモデルの発展によ って，モデルを解くこと自体が非常に困難となり，有用 な知見を得ることも難しくなりやすい. 本研究のように 数值的な解法からアプローチ寸ることで, 解析解のよう に一般的知見を簡便に示すことは犠牲となるが, 複雑な 経済システムを扱うことが比較的容易となる. 現実経済 におけるインフラストックの役割や, 維持管理とストッ ク蓄積の関係は, 本研究や既存の理論研究が仮定するよ うな単純な形で表現できているとは言い難い. 実証的な 観察を積み上げることで，こうした関係性についての知 見が深まることが期待される. 実務的な応用のためには， モデルの理論的枠組の発展のみならず，こうしたインフ ラや維持管理の本質的な効果を把握することも, 今後の 研究課題としたい.

なお，本研究は文部科学省東京大学グローバル COE プログラム「都市空間の持続再生学の展開」によって行 ったものである.

\section{参考文献}

1) 内閣府政策統括官偏: 日本の社会資本, 財務省印刷 局, 2002.

2) 国土交通省: 平成14年度国土交通白書, 2003.

3）国土交通省：国土交通白書2008, 2009.

4) 小林潔司, 上田孝行: インフラストラクチャ・マネ ジメント研究の課題と展望, 土木学会論文集, No.744/ IV-61, pp.15-27, 2003.

5) Arrow, Kenneth J., and Kurz, Mordecai. Public Investment, the Rate of Return, and Optimal Fiscal Policy. Baltimore: 
Johns Hopkins Univ. Press (for Resources for the Future), 1970.

6) Barro, R.: Government spending in a simple model of endogenous growth. Journal of Political Economy 98, pp.S103-S125, 1990.

7) King, R G. and Rebelo, S.: Public policy and economic growth: Developing neoclassical implications, Journal of Political Economy 98, pp.S126- 150., 1990.

8) Glomm, G., Ravikumar, B.: Public investment in infrastructure in a simple growth model, Journal of Economic Dynamics and Control 18 (6), pp.1173-1187, 1994.

9) Aschauer, D.A.: Is Public Expenditure Productive?, Journal of Monetary Economics 23, pp.177-200, 1989.

10) Devarajan, S., Swaroop, V., Zou, H.: The composition of public expenditure and economic growth. Journal of Monetary Economics 37 (2), pp.313-344., 1996.

11) Rioja, F.: Filling potholes: macroeconomic effects of maintenance versus new investment in public infrastructure. Journal of Public Economics 87, pp.2281-2304., 2003.

12) Kalaitzidakis,P. and Kalyvitis,S.: On the macroeconomic implications of maintenance in public capital, Journal of Public Economics 88, pp.695-712, 2004.
13) 桑島氏直, 織田澤利守: インフラの競合性と減耗の 経済成長経路に与える影響分析, 土木計画学研究・ 講演集 vol. 32, CD-ROM, 2005.

14) Dioikitopoulos, E.V., and Kalyvitis, S.: Public capital maintenance and congestion: Long-run growth and fiscal policies, Journal of Economic Dynamics and Control 32 (6), pp.1173-1187, 2008.

15）上田孝行, 横松宗太: 建設技術進歩の経済成長への 貢献 -理論的分析-, 土木計画学研究・講演集, vol.34, CD-ROM, 2006.

16) 石倉智樹: 資本減耗の制御とマクロ経済成長, 土木 計画学研究・講演集 vol. 36, CD-ROM, 2007.

17) 上田孝行, 越智成基, 横松宗太: 建設技術進歩に着目 した超長期インフラ政策, 土木計画学研究・講演集 vol. 38, CD-ROM, 2008.

18) Kamien, M.I. and Schwartz, N.L.: Dynamic Optimization, Elsevier, 1991.

19) Ljungqvist, L. and Sargent, T.: Recursive Macroeconomic Theory, The MIT Press, 2000.

20) Judd, K. L.: Numerical Methods in Economics, The MIT Press, 1998

\section{インフラ維持管理技術の変化によるマクロ経済的影響に関する基礎的モデル分析*}

インフラのストックの蓄積に伴い，維持管理費や老朽化したストックの更新などのインフラ管理費用が増大するこ とが予想されており，今後はその長期的計画が重要となる. 本研究は，長期的な視点からインフラの戦略的な維持管 理・更新政策への示唆を得るため, 維持管理によるインフラストックの劣化・滅失の制御を考慮した，基礎的な動学 的経済モデルを構築した。 さらに，仮想経済を対象としたシミュレーション分析により，インフラの維持管理技術の 変化や，インフラストックの生産性の変化が，最適成長のためのインフラ投資・維持管理政策に及ぼす影響について， 感度分析を行った.

\section{An Analysis of Macroeconomic Effects by the Change of Infrastructure Management Technology}

By Tomoki ISHIKURA**

Investment to infrastructure increases the needs of maintenance as well as accumulating the stock. Therefore the planning of Infrastructure maintenance policy will be an important issue. This paper develops an economic growth model where infrastructure maintenance technology explicitly influences to deterioration of infrastructure stock. This paper furthuremore implements some sensitive analyses assuming a virtual economy and derives some implications about the relationship between the technological improvement of infrastructure maintenance and growth rate of the economy. 